\title{
Colour of milk and milk products in CIE $L^{*} a^{*} b^{*}$ space
}

\author{
SYLWIA CHUDY, AGNIESZKA BILSKA*, RYSZARD KOWALSKI*, JOANNA TEICHERT
}

\author{
Department of Dairy Products Quality, *Department of Meat Technology, Faculty of Food Science and Nutrition, \\ Poznań University of Life Sciences, Wojska Polskiego 31/33, 60-624 Poznań, Poland
}

\section{Chudy S., Bilska A., Kowalski R., Teichert J. Colour of milk and milk products in CIE L*a*b* space}

Summary

Colour measuring instruments have become more reliable, smaller and faster than their predecessors at significantly lower costs for the users. This article has been written to provide practical guidelines for technologists, technicians and scientists to better understand colour measurement of dairy products. The results of milk colour measurement are used to determine the health of cows, as well as the quality of the raw material. The measurement of the colour of final dairy products makes it possible to determine their quality and to monitor changes occurring during storage.

The article presents the theory of colour evaluation in the CIE $L * a * b *$ space. It specifies what conditions need to be fulfilled while determining the colour and what information should be given when publishing data on colour. The article explains what affects the colour of milk. The article gives examples of studies on the colours of dairy products and practical applications of such studies.

Keywords: CIE Lab, colour, dairy products, milk

Since the colour of objects is a feature originating in human mind, the perception and interpretation of colour remains subjective. An illuminated object reflects light energy, either partially or completely. A reflected electromagnetic wave reaching an observer is captured by the eye, and, after passing the signal to the brain, an impression of colour is generated. An analogous phenomenon is observed during sunbathing. People cannot see solar radiation, but can feel it warming them up - thus an impression of warmth is created in their minds (also subjectively). Since our bodies differ, we experience impressions in different ways. The reception of colours depends on the eye structure, educational background, natural environment and mental aptitude $(27,42)$. A mood or illness can also affect colours created in the brain. Due to disturbances in the eye or brain structure, a certain percentage of society is unable to generate the whole range of colours. Thus, as an instrument of colour evaluation, man is not free from drawbacks.

An objective colour description is indispensable, particularly wherever slight differences in colour are significant, as in textile, paint and foodstuff industries or in dentistry (22). Nowadays, spectrophotometers are most frequently used for a quick evaluation of product colours. They convert energy reflected from an object into numbers defining the colour. The space for the expression of product colour is nowadays usually the CIE LAB colour space. In this space, the colour is expressed by means of three coordinates (constituents): $L^{*}, a^{*}, b^{*}$. For better visualisation of the results, constituent $\mathrm{L}^{*}$ can be presented as an independent vertical line with the following values: 0 - black, medium values - greys, and 100 - white. Values $a^{*}$ and $b^{*}$ can be presented as a point in the ab coordinate system, that is, on a colourful plane where colours fluently pass from red $\left(+\mathrm{a}^{*}\right)$ through yellow $\left(+\mathrm{b}^{*}\right)$ to green $\left(-\mathrm{a}^{*}\right)$ and blue $\left(-b^{*}\right)$, just like the colours of the white light spectrum after passing through a prism. By connecting a point with coordinates $a^{*} b^{*}$ with the centre of the coordinate system, a segment line is obtained, whose length is defined as chrome (c). The higher the value of c, the more intense (stronger and clearer) the colour of the object, and vice versa: the lower the c (closer to the centre of the system), the paler grey the colour is. The angle created by the axis $+a^{*}$ and the line segment $\mathrm{c}$ is called the hue (i.e. colour), and denoted by the letter $h$. The parameters obtained while measuring colour depend on spectrophotometer settings: the source of light (31), the angle of light incidence and observation (measurement geometry), the observation angle of the observer $\left(2^{\circ}\right.$ or $\left.10^{\circ}\right)$, the diameter of the measurement area, and, for thin layers of samples, the parameters depend on the surface colour $(3,45)$. The 
most preferred source of light is the equivalent of daylight, marked with the symbol D65. The $10^{\circ}$ observer was developed as an improvement on the original $2^{\circ}$ (30). When describing research, it is recommended to give information on the model according to which the colour measuring device was calibrated. Most spectrophotometers used for measuring light in a colour management system have an opening with a diameter of 4-8 $\mathrm{mm}$. The bigger the opening, the lower the influence of surface differences on the measurement. When describing research on liquid and loose products, the type of the tray should be given, and it should be specified whether the measurement was made through the tray glass.

Preparing the sample is a fundamental problem of colour measurement. During the analysis of stable samples, it should be remembered that

- the sample should be flat (for dispersed light to be homogeneous),

- the structure of subsurface layers and dustiness affect light dispersion,

- the structure of pigments depends on the temperature of the product examined,

- the measurement opening needs to be adjusted to the size of the sample (the sizes of the opening and the sample need to be given),

- light sources in measuring devices are very intense, so the type of surface on which the sample is placed can affect measurement results,

- dry samples are darker than those with an increased water content,

- the number of repetitions needs to be calculated for the material tested,

- the description of samples should include their chemical content.

Cheng at al. (9) demonstrated that also the temperature of the sample and the measurement system (CIE, Hunter) should be specified.

In their research, Chudy et al. (10) calculated the necessary number of repetitions, depending on the adopted measurement error. An X-Rite spectrophotometer (SP60) was used in this study with the following settings: measuring geometry $-\mathrm{d} / 8$, measurement opening $-8 \mathrm{~mm}$, normalized light source - D65, normalized observer $-10^{\circ}$, setting option SPEX. For a $2 \%$ error, the number of repetitions, depending on the system, was as follows: CIE Lch - 10, CIE Lab - 13 for ripening rennet cheese; CIE Lch - 2, CIE Lab - 33 for butter; and CIE Lch system - 9, CEL Lab - 22 for processed cheese. The most repetitive parameter describing the colour of processed cheese was h (hue). Even for a $1 \%$ error level, only 2 repetitions were required for ripened cheese and processed cheese, and one repetition for butter. The authors determined that, depending on the size of indication error, the lab/researcher should decide on a different number of repeats which need to be performed when defining product colour. If the indication error is to be small, e.g. $1 \%$, more repetitions are required for the results to be reliable.

Visual comparison of colours is based on differences in hue (h), intensity/chroma (c) and lightness ( $\left.\mathrm{L}^{*}\right)$. The human eye can see differences in hue easier than those in chroma. Therefore, the most stringent criteria are those pertaining to the difference in hue. With an increase in $\mathrm{c}$, the ability of the human eye to capture differences in the constituents of colour $\left(\mathrm{L}^{*}, \mathrm{a}^{*}, \mathrm{~b}^{*}\right)$ increases. Most often, the correlation of lightness, intensity and hue is assumed as the ratio of $\mathrm{L}^{*}: \mathrm{c}: \mathrm{h}=$ $4: 2: 1$ (34). The $\mathrm{L}^{*}, \mathrm{a}^{*}, \mathrm{~b}^{*}$ values can be used to calculate the value of colour difference $(\Delta \mathrm{E})$ for comparison between two samples, $\Delta \mathrm{E}=\left[\Delta \mathrm{L}^{* 2}+\Delta \mathrm{a}^{* 2}+\Delta \mathrm{b}^{* 2}\right]^{0.5}$. Numerical values of the accepted colour deviations should, nevertheless, be varied, depending on colour, intensity and product type (26).

\section{Factors affecting milk colour}

The appearance of milk is white. It results from its physical and chemical structure (38). The natural colour of milk is due to the reflection of light by dispersed fat globules, calcium caseinate and calcium phosphate. Milk also contains two classes of pigments: water-soluble and fat-soluble ones. The water-soluble pigment, which imparts a yellow colour with green fluorescence to the whey of milk, was called lactoflavin. It is better known as riboflavin or vitamin $B_{2}$, but is also referred to as vitamin $G$ or lactochrome (19). Milk is relatively rich in this vitamin. The riboflavin content in cow's milk ranged from 1.16 to $1.31 \mu \mathrm{g} \mathrm{ml}^{-1}$. Riboflavin is heat stable and light sensitive. For cow's milk stored in opened containers in a refrigerator at $8^{\circ} \mathrm{C}$ (in the dark), the loss of riboflavin ranged from $16.0 \%$ to $23.4 \%$ (37). A fat-soluble pigment found in fat gives fat-rich milk products a more or less yellow tinge. The depth of colour depends on the amount of pigment present. The group of pigments called carotinoids includes $\beta$-carotene, retinol and xanthophylls (i.e. lutein and zeaxanthin). The colour of carotene varies from yellow to orange and deep red-orange as the concentration increases. The amount of carotene in butter oil depends on the amount of carotene in the food of cows (2). Carotenoids are synthesized in plants, but not in animals. Green grasses, hay carrots and corn are rich in carotene. In their study, Mogensen et al. (35) found concentrations of 0.17 and $0.41 \mathrm{mg}$ of $\beta$-carotene and retinol, respectively, per one litre of milk in five organic dairy herds in Denmark. Many factors have been suggested to explain the variability in carotenoids in milk, including non-dietary factors, such as breed, stage of lactation, health status of the udder, milk and fat yields as well as genetic traits (19). The yellow coloration is higher for Jersey cows than it is for Holstein or Montbélliarde cows. Also Guernseys are known for the deep yellow colour of the fat in their milk due to $\beta$-carotene retained from feed 
$(5,15)$. Goat's and ewe's milk, in contrast, contains no $\beta$-carotene, only retinol and xantophylls $(41,47)$. Goats and ewes convert $\beta$-carotene (from plants) into vitamin $A$, which lacks colour.

Milk can also be reddish or pinkish because of the presence of blood. There are several causes of blood in milk. Important causes of this disorder are haemorrhage, systemic microbial infections (several infections, including those caused by some bacteria, some viruses and red yeast), feeds containing natural toxins or dyes, deficiency of blood platelets and other causes (vitamin $\mathrm{C}$ deficiency, rough milking and acute or chronic mastitis) (36). Inflammation is characterised by changes in the composition and appearance of milk. Abnormalities in milk may include the presence of flakes and clots or watery appearance.

Cow's colostrum - the first secretion of the mammary gland after parturition (characterised by its high content of immunoglobulins, predominantly IgG) - can have a wide colour spectrum, from dark brown/red through yellow to pale white (20). Colostrum generally contains higher concentrations of $\beta$-carotene and retinol (23). In the course of a couple of days, colostrum turns into milk in its appearance and content.

Data $(29,46)$ show that the colour of milk can be changed by controlled feeding as well as by genetic manipulation of cows.

\section{Colour of dairy products and practical application of colour evaluation in dairy industry}

The yellow coloration of dairy products is generally more important in high-fat dairy products, such as butter and full-fat cheeses. Because carotenoids are fat-soluble, the yellow coloration is a function of both fat colour and concentration, and fat colour in its turn is a function of carotenoid concentration in fat (49). The colours of selected products are presented in Table 1 . As can be seen, the natural colour of dairy products is situated in the $1^{\text {st }}$ and $2^{\text {nd }}$ quarters of the coordinate system with the $a^{*}$ and $b^{*}$ axes, which is indicative of the colour yellow. The yellow colour of products can be monochromatic $(580 \mathrm{~nm})$ or generated by a greenish $(540-560 \mathrm{~nm})$ and red $(600-700 \mathrm{~nm})$ radiation mixture.

Scientific publications frequently lack data on the light source of the device used or the measurement geometry. One practical application of colour measurement was found by Everard et al. (17). They used colour parameters to monitor curd syneresis during cheese making. El-Nimr et al. (16) used colour measurement to monitor changes in colour and to determine correlations between sensory evaluation and colour parameters during the ripening of cheese.

Since the colour of the product affects its reception by consumers, research on how colour influences human senses is both important and interesting. Research results (8) indicated that, even with the same content of each fruit flavour and sugar, the greater the concentration of colorant, the greater was the intensity of taste perceived by the assessors in yoghurts with strawberry, orange and fruit of the forest flavours. With regard to the perception of sweetness, only in yoghurts with fruit of the forest flavour was a greater concentration of colorant associated with a greater sensation of sweetness. Rohm et al. (43) proved that sensory spreadability is heavily affected by butter colour. The more yellowish butter was selected and described by consumers as "easier to spread" (43). It can be concluded from research (16) that cheeses scored better in sensory evaluation with increasing $\mathrm{a}^{*}$ and $\mathrm{b}^{*}$ and with decreasing $\mathrm{L}^{*}$. The colour of butter may vary from light, creamy white to orange yellow. Differences in butter colour result from variation in the colour of butter fat, variation in the size of fat globules, the presence or absence of salt, the condition of working butter (21), the type of packaging and storage temperature (1). The colour of dairy products also depends on the type and amount of colouring added. The European Union permits carotenes (E160a), annatto, bixin and norbixin (E160b) as additives to ripened cheeses, and 13 types of colorants, including lutein, as additives to processed cheese (12). Jones et al. (25) and Kubo et al. (28) experimented with adding lutein as colouring. The objectives of their study were to determine the transference of lutein additive (dye) from milk to whey and cheese, to evaluate the effect of lutein addition, light exposure and storage time on cheese colour and to verify the sensory acceptance of Prato cheese with addition of lutein. Technological processes, as well as conditions and time of storage, can result in colour changes in dairy products. Homogenisation causes an

Tab. 1. Examples of colours of dairy products expressed in CIE $L * a * b *$ system

\begin{tabular}{|c|c|c|c|c|c|}
\hline Product & $L^{*}$ & $a^{*}$ & $\mathbf{b}^{*}$ & Conditions & Source \\
\hline Yoghurt ( $2 \%$ fat; $\mathrm{pH}=4.40)$ & 92.07 & -2.64 & 9.14 & $10-12^{\circ} \mathrm{C}$ & (7) \\
\hline Butter ( $83 \%$ fat, protein and carbohydrates $0.7 \%$ of each) & 90.53 & 1.29 & 18.03 & $\mathrm{D} 65 / 10^{\circ}, 8^{\circ} \mathrm{C}$ & (10) \\
\hline Butter & 91.6 & 5.5 & 24.7 & $\mathrm{D} 65 / 10^{\circ}, 15^{\circ} \mathrm{C}$ & (43) \\
\hline Maturing rennet cheese ( $27 \%$ fat, $26 \%$ protein, $1.2 \%$ carbohydrates) & 77.17 & 8.25 & 32.16 & $\mathrm{D} 65 / 10^{\circ}, 8^{\circ} \mathrm{C}$ & (11) \\
\hline Mild Cheddar cheese (30.5-32.5\% fat) & 69.6 & 9.6 & 28.7 & D65 & (49) \\
\hline Demineralised whey (75.6\% lactose, $15.5 \%$ protein, $3.7 \%$ mineral salts, $1.1 \%$ fat) & 95.46 & -0.68 & 13.93 & ${ }^{* *} \mathrm{D} 65 / 10^{\circ}, 20^{\circ} \mathrm{C}$ & authors \\
\hline
\end{tabular}

Explanations: $* *$ - measuring equipment: spectrophotometer X-Rite SP-60, glass cuvette; $\mathrm{n}=10$ 
increase in whiteness (cream, milk), whereas thermal processes may cause either an increase or a decrease in parameter $\mathrm{L}^{*}(6)$. An increase in lightness occurs due to denaturation of $\beta$-lactoglobulin and its conjugation to j-casein. Devi et al. (13) proved that coloured products from high-pressure thermal processing (HPTP) of skim milk come primarily from lactose degradation. The rates of colour changes and proteolysis increased with increasing temperature and duration of HPTP. The colour of milk changed drastically at $400 \mathrm{MPa}$, where most of milk proteins formed coagulates and left the solution nearly translucent. The colour of skim milk changed from white to caramel brown during HPTP at $400 \mathrm{MPa}$ and 100,110 and $120^{\circ} \mathrm{C}$.

Popov-Raljić et al. (40) examined colour changes in UHT milk with a fat content of $3.2 \%$ stored at a temperature of $20 \pm 5^{\circ} \mathrm{C}$ for 90 days. They noted changes in $\mathrm{L}^{*}$ from 89.88 to 77.15 , in $\mathrm{a}^{*}$ from -3.26 to 2.12 and in $b^{*}$ from 9.27 to 7.06 .

As shown by Chudy et al. (11), during storage of whole milk powder $(26.4 \%$ of fat $)$ at $20^{\circ} \mathrm{C}$, both vacuum-packed powders and those packed in the environment of air became darker ( $\mathrm{L}^{*}$ value decreased) by month 12 of storage and then lighter $\left(\mathrm{L}^{*}\right.$ value increased) by month 24 of storage. The darkening of products in storage could be caused by non-enzymatic browning reactions (Maillard reactions, lipid peroxidation, degradation of ascorbic acid or sugar-sugar caramelisation). The reaction of the amino group of lysine and the carbonyl group of lactose is the main one in whole milk powder. Pentose or xylose undergo dehydration and, losing a water molecule, become furfural or hydroxymethylfurfural (HMF) (32). In fresh milk powder, lactose appears in an amorphous (i.e. non-crystalline) form. With an increase in water level (around 5-7\%), there is a threat of lactose crystallisation. Forming crystals cause relocation of other components, thereby undergoing local densification and stronger interaction with one another. An increase in salt concentration at a given point of milk granule may lead to denaturing alternations in casein.

Colour changes occurring during the production and ripening of cheese were described by Johnson (24). Each phase of cheese - solid and liquid - contains material that reflects specific wavelengths of light and therefore different colours of products. Light reflected from some components of cheese may overwhelm light reflected from other components. This can change with time, and that is why the colour of cheese can change with cheese age. Proteolysis that occurs during ripening can transform casein into a more soluble state and can cause a decrease in whiteness. Beta-caroten is very stable, whereas xanthphylls are partially damaged and/ or lost into whey during cheese making (49). The colour of cheese also depends on its acidity. Mozzarella was whiter at the $\mathrm{pH}$ of 5.2 than at 5.0, when translucent areas were observed (24). Changes in the colour of Garrotxa cheese during regular ripening and at high hydrostatic pressure (HHP) were studied by Saldo at al. (44). The decrease in cheese lightness (L-values) during ripening was associated with the concentration of cheese components. The moisture content in cheese during ripening decreased by $32 \%$ in regular cheese and by $23.95 \%$ in cheese subjected to HHP. HHP treatment at the beginning of cheese ripening proved successful in accelerating the process. This treatment leads to increased proteolysis, a higher moisture content and a higher $\mathrm{pH}$.

The metabolism of bacteria in cheese may lead to the formation of dicarbonyl compounds that react with amino acids. The reaction produces pink or brown pigments (Maillard browning). Bacteria, moulds or yeast may also produce other pigments. In the initial stages of ripening, yeasts such as Debaryomyces hansenii constitute a major part of the surface microflora of red-smear cheeses and contribute to the ripening by assimilation of lactic acid causing an increase in $\mathrm{pH}$, which enhances the growth of pigmented coryneform bacteria. $D$. hansenii and other yeasts have a significant effect on the intensity of an orange-reddish colour (14). Arthrobacter nicotianae give a reddish-brown colour to semi-hard smear cheese. Yellow and orange strains of coryneform bacteria form a major part of the surface flora of smear cheese. Yellow, orange or red pigment is also produced by Brevibacterium linens (4). Galaup et al. (18) isolated 364 strains from Munster cheese (219 coryneform bacteria, 32 Micrococcus, 30 Staphylococus and 83 B. linens). Besides orange and yellow, a lot of strains were light coloured (beige or cream), and five were pink. Paul-Sadhu (39) proved a significant correlation between the number of bacteria in fluid pasteurised skim milk and the values of $\mathrm{L}^{*}, \mathrm{a}^{*}$ and $b^{*}$ obtained from colour measurement.

Colour coordinates, chroma and hue can also indicate changes in fat. As reported by Méndez-Cid et al. (33), the peroxide value exhibits high correlations with $h(0.788), L^{*}(0.612)$ and $b^{*}(-0.631)$ and smaller ones with $\mathrm{c}(-0.598)$ and $\mathrm{a}^{*}(-0.332)$.

The use of colour measuring devices can ensure an objective evaluation and control of colours. These devices can be used for precisely identifying and comparing the colours of products. Thanks to the measurement of colours, technological changes can be introduced to maintain the parameters of colours or to adjust the colours of products to customer expectations. It is necessary to provide detailed descriptions of the measurements conducted so that the experiments can be repeated and their results compared with others.

\section{References}

1. Ahmed J., Ramaswamy H. S., Raghavan V. G.: Dielectric properties of butter in the MW frequency range as affected by salt and temperature. J. Food Eng. 2007, 82, 351-358.

2. Antone U., Zagorska J., Sterna V., Jemeljanovs A., Berzins A., Ikauniec D. Effects of dairy cow diet supplementation with carrots on milk composition, 
concentration of cow blood serum carotenes, and butter oil fat-soluble antioxidative substances. Agronomy Res. 2015, 13, 879-891.

3. Bianchi M., Fletcher D. L.: Effects of broiler breast meat thickness and background on color measurements. Poultry Sci. 2002, 81, 1766-1769.

4. Bockelmann W., Hoppe-Seyler T.: The surface flora of bacterial smear-ripened cheeses from cow's and goat's milk. Int. Dairy J. 2001, 11, 307-314.

5. Budlo P., Wiking L.: Butter: Properties and analysis, [in:] Caballero B., Finglas P., Toldrá F. (ed.): Encyclopedia of Food and Health. Elsevier 2016, p. 535-541.

6. Burton $H$.: Chemical and physical changes in milk at high temperatures, [in:] Ultra-high-temperature processing of milk and milk products. Springer US, New York 1994, p. 44-76.

7. Cais-Sokolińska D., Pikul J.: Use of colour measurement to evaluate yoghurt quality during storage. Ital. J. Food Sci. 2006, 18, 63-71.

8. Calvo C., Salvador A., Fiszman S. M.: Influence of color intensity on the perception of color and sweetness in various fruit-flavoured yoghurts. Euro. Food Res. Technol. 2001, 213, 99-103.

9. Cheng N., Barbano D. M., Drake M. A.: Hunter versus CIE color measurement systems for analysis of milk-based beverages. J. Dairy Sci. 2018, 101, 4891-4905, doi: 10.3168/jds.2017-14197.

10. Chudy S., Gieraltowska U., Krzywdzińska-Bartkowiak M., Piątek M.: Pomiar barwy produktów mleczarskich, [in:] Cegielska-Radziejewska R., PiaseckaKwiatkowska D. (red.): Współczesne trendy w kształtowaniu jakości żywności. Uniwersytet Przyrodniczy w Poznaniu 2016, p. 85-95.

11. Chudy S., Pikul J., Rudzinska M., Makowska A.: The effect of storage on physicochemical properties of spray-dried milk, egg and milk-egg mixture. Acta Agroph. 2015, 22, 17-26.

12. Commission Regulation EU No 1129/2011 Union list of food additives.

13.Devi A. F., Buckow R., Singh T., Hemar Y., Kasapis S.: Color change and proteolysis of skim milk during high pressure thermal-processing. J. Food Eng. 2015, 147, 102-110.

14.Dufossé L., Galaup P., Carlet E., Flamin C., Valla A.: Spectrocolorimetry in the CIE $\mathrm{L}^{*} \mathrm{a}^{*} \mathrm{~b}^{*}$ color space as useful tool for monitoring the ripening process and the quality of PDO red-smear soft cheeses. Food Res. Int. 2005, 38, 919-924.

15. Dufossé L., Galaup S.: Color, [in:] Nollet L. M. L., Toldra F. (ed.): Handbook of Dairy Food Analysis. CRC Press New York 2009, p. 581-602.

16. El-Nimr A. A., Eissa H. A., El-Abd M. M., Mehriz A. A., Abbas H. M., Bayoumi H. M.: Water Activity, Color Characteristics and Sensory Properties of Egyptian Gouda during Ripening. J. Am. Sci. 2010, 6, 446-453.

17. Everard C. D., O'Callaghan D. J., Mateo M. J., Castillo M., Payne F. A., O'Donnell C. P.: The use of color parameters derived from an online fibreoptic sensor to monitor curd syneresis during cheese making. J. Food Eng. 2009, 94, 1-6.

18. Galaup P., Flamin C., Carlet E., Dufossé L.: HPLC analysis of the pigments produced by the microflora isolated from the 'Protected Designation of Origin' French red-smear soft cheeses Munster, Epoisses, Reblochon and Livarot. Food Res. Int. 2005, 38, 855-860.

19. Graulet B.: Improving the level of vitamins in milk, [in:] Griffiths M. W. (ed.): Improving the Safety and Quality of Milk. Improving Quality in Milk Products. Woodhead Publishing Ltd, Cambridge 2010, p. 229-251.

20. Gross J. J., Kessler E. C., Bruckmaier M. R.: Color measurement of colostrum for estimation of colostral $\mathrm{IgG}$ and colostrum composition in dairy cows. J. Dairy Res. 2014, 81, 440-444

21. Hettinga D.: Butter. Bailey's Industrial Oil and Fat Products. Sixth Edition, Six Volume Set. Ed Fereidoon Shahidi. John Wiley \& Sons Inc., Hoboken, New Jersey 2005.

22. Hunt R. W. G., Pointer M. R.: Measuring Color. John Wiley \& Sons Inc., New York 2011.

23. Jensen S. K., Johannsen A. K. B., Hermansen J. E.: Quantitative secretion and maximal secretion capacity of retinol, beta-carotene and alpha-tocopherol into cows' milk. J. Dairy Res. 1999, 66, 511-522.

24. Johnson M.: Casein - How it colors cheese. Dairy Pipeline - Wisconsin Center for Dairy Research 1999, 11, 1-5.

25. Jones S. T., Aryana K. J., Losso J. N.: Storage stability of lutein during ripening of cheddar cheese. J. Dairy Sci. 2005, 88, 1661-1670.

26. Kazimierska M: Objective evaluation of colour of useable products. Technologia i Jakość Wyrobów 2014, 59, 1-4.

27. Kose E.: Modelling of color perception of different age groups using artificial neural networks. Expert Syst. Appl. 2008, 34, 2129-2139.

28. Kubo M. T. K., Maus D., Xavier A. A. O., Mercadante A. Z., Viotto W. H.: Transference of lutein during cheese making, color stability, and sensory acceptance of Prato cheese. Food Sci. Technol. 2013, 33, 82-88.
29. Laible G. L., Brophy B., Knighton D., Wells D. N.: Compositional analysis of dairy products derived from clones and cloned transgenic cattle. Theriogenology 2007, 1, 67, 166-177. doi: 10.1016/j.theriogenology.2006.09.028.

30. Loughrey K.: Overview of color analysis. Curr. Protoc. Food Anal. Chem. 2002, 1-13.

31. MacDougall D.: Colour measurement of food: principles and practice, [in:] MacDougall D. (ed.): Colour in Food. Improving quality. Woodhead Publishing, England 2002, p. 57-59.

32. Makawi S. Z. A., Taha M. I., Zakaria B. A., Siddig B., Mahmod H., Elhussein A. R. M., Kariem E. A. G.: Identification and quantification of 5-hydroxymethyl furfural HMF in some sugar-containing food products by HPLC. Pak. J. Nutr. 2009, 8, 1391-1396.

33. Méndez-Cid F., Lorenzo J. M., Martínez S., Carballo J.: Oxidation of edible animal fat. Comparsion of the performance of different quantification methods and of a proposed new semi-objective colour scale-based method. Food Chem. 2017, 217, 743-749.

34. Mielicki J.: Zarys wiadomości o barwie. Fund. Rozw. Pol. Kolor., Łódź 1997

35. Mogensen L., Kristensen T., Søegaard K., Jensen S. K., Sehested J.: Alfatocopherol and beta-carotene in roughages and milk in organic dairy herds. Livestock Sci. 2012, 145, 44-54.

36. Muhammad G., Rashid I., Ullah Q.: Causes, diagnosis and treatment of blood in milk (hemolactia) in cows and buffaloes. Scholar's Adv. Anim. Vet. Res. 2015, 2, 1-6.

37. Muñoz A., Ortiz R., Murcia M. A.: Determination by HPLC of changes in riboflavin levels in milk and nondairy imitation milk during refrigerated storage. Food Chem. 1994, 49, 203-206.

38. Nozière P., Graulet B., Lucas A., Martin B., Grolier P., Doreau M.: Carotenoids for ruminants: from forages to dairy products. Anim. Feed Sci. Tech. 2006, 131, 418-450.

39. Paul-Sadhu S.: Impact of low refrigeration temperature on colour of milk. Acta Alimentaria 45, 390-397, doi: 10.1556/066.2016.45.3.10.

40. Popov-Raljić J. V., Lakić N. S., Laličić-Petronijević J. G., Barać M. B., Sikimić V. M.: Color changes of UHT milk during storage. Sensors 2008, 8, 5961-5974.

41. Raynal L. K., Lagiffoul G., Paccard P., Guillet I., Chillaiard Y.: Composition of goat and sheep milk products. An update. Small Ruminant Res. 2008, 79, $57-72$.

42. Roberson D., Pak H., Hanley J. R.: Categorical perception of color in the left and right visual field is verbally mediated: Evidence, Korean, Cognition 2008, $107,752-762$.

43. Rohm H., Strobl M., Jaros D.: Butter color affects sensory perception of spreadability. Z. Lebensm. Unters. Forsch. 1997, 205, 108-110, doi: 10.1007/ s002170050134

44. Saldo J., Sendra E., Guamis B.: Color changes during ripening of high pressure treated hard caprine cheese. High Press. Res. 2002, 22, 659-663.

45. Sandusky C. L., Heath J. L.: Effect of background color, sample thickness, and illuminant on the measurement of broiler meat color. Poultry Sci. 1996, 75, 1437-1442.

46. Solah V. A., Staines V., Honda S., Limley H. A.: Measurement of milk color and composition: effect of dietary intervention on Western Australian Holstein-Friesian cow's milk quality. J. Food Sci. 2007, 72, S560-566, doi: 10.1111/j.1750-3841.2007.00491.x.

47. Ullah R., Khan S., Ali H., Bilal M., Saleem M., Mahmood A., Ahmed M.: Raman-spectroscopy-based differentiation between cow and buffalo milk. J. Raman Spectrosc. 2017, 48, 692-696.

48. Wadhwani R., McMahon D. J.: Color of low-fat cheese influences flavor perception and consumer liking. J. Dairy Sci. 2012, 95, 2336-2346.

49. Wendorff B., Paulus K.: Impact of breed on cheesemaking potential of milk; Volume vs Content. Dairy Pipeline - Wisconsin Center for Dairy Reasearch 2011, 23, 4-7.

Corresponding author: Agnieszka Bilska, Eng. PhD, Wojska Polskiego 31/33, 60-624 Poznań, Poland; e-mail: agnieszka.bilska@up.poznan.pl 